\title{
Effects of Climate Change on Growth and Development of Chilli
}

\author{
Karma Bhutia L, Khanna VK*, Tombisana Meetei NG and Nangsol Bhutia D
}

School of Crop Improvement, College of Post-Graduate Studies, Central Agricultural University, Barapani, Umiam-793103, Meghalaya, India

\begin{abstract}
Climate change has become the major concern for the world today. Focusing on agriculture, climate change is already beginning to have a negative impact on world's crop production levels. Global warming/climate change is causing a significant harm to the cultivation of crops including chillies around the world. Chilli is one of the important spice crops. Many studies have been done/conducted to look for the possible damage to chilli crop growth and development due to change in climate and global warming and also to find out the solution to these problems. This review article highlights about some of the consequences of global warming such as extreme temperature, drought, floods, soil acidity, soil salinity, etc. on chilli and the mitigation and adaptation techniques that are being used or can be used to make the plants more tolerant and productive under this changing climate.
\end{abstract}

Keywords: Climate change; Global warming; Chilli; Rainfall; Greenhouse gases

\section{Introduction}

Chillies (Capsicum spp.) are the berries or fruits of plant belonging to the genus Capsicum of the solanaceae family. It has its centre of origin in American tropics. It is used as spice in a variety of cuisines all over the world as a basic ingredient. Capsicum not only gives attractive color and flavor to the foods but also provides vitamin $\mathrm{C}$, vitamin $\mathrm{A}$, vitamin B complex, vitamin $\mathrm{E}$ and minerals. Capsaicin present in chilli pepper is used as medicine for treatment of many human diseases like Lumbago, Neuralgia, Rheumatic disorders and non-allergic Rhinitis, etc. There are thought to be 25-30 species of Capsicum of which 5 species i.e. C. annum L, C. frutescens mill, C. chinense, C. baccatum $\mathrm{L}$, and C. pubescens have been domesticated and cultivated [1]. It is a self-pollinated dicot plant. However, there is an occurrence of cross pollination which leads to the formation of variants within the species. It is grown in the world on an area of 1.5 million ha with a production of about 10.60 million tonnes of green and dried chillies [2]. India ranks first in the world with an area of 7.75 lakh ha with an average yield of 1.6 metric tonne/ha [3]. India contributes about $36 \%$ of the total world's production [4] and in terms of international trade India remained in first position by exporting nearly $30 \%$ from its total production [5]. Chilles from India are mainly exported to Asian countries like Vietnam, Thailand, Sri Lanka, Bangladesh and UAE. [5].

There are several factors which affect the production and productivity of crop among which climate is the primary determinant of crop productivity and is expected to influence crop, hydrologic balances, input supplies and other components of agricultural systems. Fourth Inter governmental panel on climate change (IPCC) strongly highlighted about the global and regional impacts of projected climate change especially on agriculture, water resources, natural eco-systems and food nutritional security [6]. Changes in climatic factors such as temperature, precipitation and the frequency and severity of extreme events like drought, floods, and wind storms directly affects the crop yields [7]. Due to urbanization, industrialization and several other reasons, the climate change has become the major issue to be deal with by the world community. One of the major problems associated with climate change is the global warming, and the main reason of global warming is the generation and accumulation of greenhouse gases in the earth atmosphere (Table 1). The changes in environment have direct impact on crop growth and yield including chilliies and the yield attributing traits of chillies vary from environment to environment [8].

\begin{tabular}{|c|c|c|}
\hline Greenhouse gas & Conc. in $\mathbf{2 0 1 0}(\mathbf{p p m})$ & $\begin{array}{c}\text { Increase since pre- } \\
\text { industrial time }\end{array}$ \\
\hline Carbon dioxide & 389 & $39 \mathrm{ppm}$ \\
Methane & 1808 & $158 \mathrm{ppb}$ \\
Nitrous oxide & 323.2 & $20 \mathrm{ppb}$ \\
\hline
\end{tabular}

Table 1: Increase in atmospheric concentration of greenhouse gases since preindustrial times [9].

Like other crops, the growth, development and yield of chilli is also influenced by the climate change. The rise in temperature, heavy rainfall, drought, soil salinity, soil acidity, occurrence of diseases and insect pest attack has severely affected the productivity of the chilli (Figure 1).

\section{Influence of Temperature on Growth and Development of Chilli}

One of the adverse effects of climate change is global warming that is rise in global temperature due to the generation and accumulation of greenhouse gases. The mean annual temperature of India has increased by $0.46^{\circ} \mathrm{C}$ over a period of the last 111 years since $1901\left(24.23^{\circ} \mathrm{C}\right)$ to $2012\left(24^{\circ} \mathrm{C}\right)$ [9]. Crop growth is indirectly controlled by temperature due to the balance between photosynthesis and respiration rates [10]. High temperature influences many aspects of plant physiology and growth, which in turn may have a direct or indirect effect on crop yield [11]. Many studies have shown the direct influence of increased or decreased temperature in the production of chilli [12]. The bell peppers which were grown under high temperature $\left(33^{\circ} \mathrm{C}\right)$ showed reduced fruit set [10], and flower malformation when grown in temperatures below $18^{\circ} \mathrm{C}$ resulting in the formation of parthenocarpic fruits and reduced fruit set [13]. The number of leaves that developed from

*Corresponding author: Khanna VK, School of Crop Improvement, College of Post-Graduate Studies, Central Agricultural University, Barapani, Umiam-793103, Meghalaya, India, Tel: 09436997876; E-mail: khannavk@rediff.com

Received August 24, 2018; Accepted October 03, 2018; Published October 12 2018

Citation: Bhutia KL, Khanna VK, Meetei TNG, Bhutia ND (2018) Effects of Climate Change on Growth and Development of Chilli. Agrotechnology 7: 180. doi: 10.4172/2168-9881.1000180

Copyright: $\odot 2018$ Bhutia KL, et al. This is an open-access article distributed under the terms of the Creative Commons Attribution License, which permits unrestricted use, distribution, and reproduction in any medium, provided the original author and source are credited. 


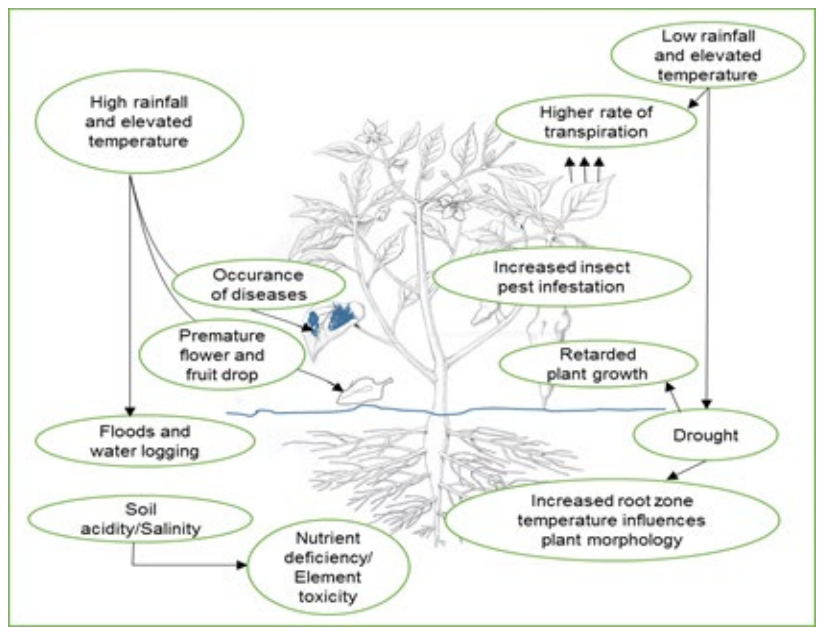

Figure 1: Effects of climate change on growth and development of chilli.

the cotyledon stage until flowering were reduced when the pepper (Capsicum annuum) were grown where the soil and night temperature were high [14]. The changes in day and night temperature markedly influenced the seedling morphology of sweet pepper. Higher day temperature and lower night temperature resulted in seedlings with darker green color leaves and higher numbers of nodes till the first flower [15]. The temperature also plays a role in occurrence of diseases in chilli. The elevated temperature along with elevated $\mathrm{CO}_{2}$ significantly increased the incidence of diseases viz. bacterial wilt, bacterial spot and anthracnose caused by Ralstonia solanacearum, Xanthomonas campestris pv. vesicatoria and Colletotrichum acutatum, respectively, whereas, the incidence of Phytophthora blight caused by Phytophthora capsici in chili was decreased at elevated temperature [16]. The infection of necrotic spot tospovirus in chilli was also favoured by high temperature [17]. The study on effect of root zone temperature on growth of chilli pepper showed that the plants growing on root zone temperature of $20^{\circ} \mathrm{C}+/-2^{\circ} \mathrm{C}$ had more leaves, greater leaf area and dry weight than plants growing on root zone temperature of $25^{\circ} \mathrm{C}-40^{\circ} \mathrm{C}$ [18]. Pollen viability and germination are known to be sensitive to high temperature. Pepper plants maintained under a moderate high temperature regime $\left(32^{\circ} \mathrm{C} / 26^{\circ} \mathrm{C}\right.$, day/night) for 8 days before flowers have reached anthesis showed reduced in vitro germination resulting in reduced number of seeds per fruit [19]. The higher temperature was also found to be correlated with capsaicin content of chilli pepper, where high temperature during the growth period showed increase in capsaicin content of the chilli pepper [20]. The temperature stress affects the yield attributing traits of chilli such as plant height, branches, canopy diameter, fruit weight, transplant success, fruit diameter and number of fruits per plant which leads to poor growth and development of chilli plants resulting in reduction in fruit yield [21].

\section{Influence of Rainfall in Growth and Development of Chilli}

Increase in global temperatures due to climate change have altered the timing and amount of rainfall, availability of water and caused the frequent occurrence of weather extremes such as drought and floods [22]. Kumar and co-workers [23] studied the monthly, seasonal and annual trends of rainfall using monthly data series of 135 years (1871-2005) for 30 sub-divisions (sub-regions) of India (Figure 2). The sub-divisional rainfall trends showed a large variability. There were increasing trends in annual rainfall in nearly half of the sub-divisions

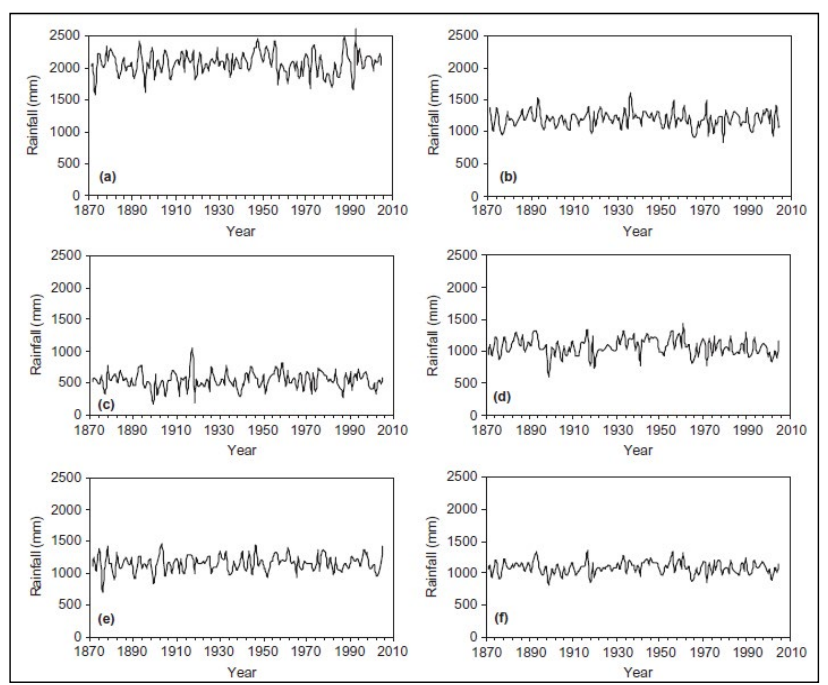

Figure 2: Temporal variation of annual rainfall in different regions of India (a) North East, (b) Central North East, (c) North West, (d) West Central, (e) Peninsular, and (f) all-regions. Source: Kumar et al.

and the other half showed the opposite trend [23]. The drought condition adversely affects the germination of seeds and also has other negative effects on crop growth and development [22].

It is estimated that due to limited availability of water for irrigation, the cultivation of crop is possible in only $16 \%$ of the potential arable area [24]. The occurrence of drought increases the concentration of salts in the soil which affects the reverse osmosis of loss of water from plant cells. This leads to poor plant growth and reduces productivity due to inhibition of several physiological and biochemical processes such as photosynthesis and respiration, etc. [25]. However, the drought stress is well recognized as an environmental condition that influences the accumulation of capsaicinoids (capsaicin and several related compounds), alkaloids in hot pepper that cause the sensation of heat, when eaten in chilli peppers [26]. The young seedlings of chilli cannot withstand either deficit or excess of soil moisture. However, the older seedlings can tolerate moisture stress comparatively to certain extent [27]. The distribution of rainfall throughout the growing season of chilli also acts as an important factor which influences the growth and yield. Unequal distribution of rainfall causes severe yield loss due to several physiological and biochemical adversities and infestations by insect pests and diseases [7]. Less rainfall or dry weather during the crop growing season encourages the infestation by thrips [28] which is one of the main insect that damages the chilli plants [29]. The increase in temperature and moisture stress (low moisture) causes early flowering in chilli plants and many other phenotypic changes that lead to poor growth and yield [22].

\section{Effects of Soil Acidity and Salinity on Chilli}

Soil acidity and salinity are among the most deleterious abiotic stresses affecting crop productivity and are responsible for significant crop loss globally. Acidity and salinity makes the soil unsuitable for crop cultivation due to various reasons like immobilization of nutrients like phosphorus and increased levels of toxic forms of elements such as aluminum and iron. According to Brunner and Sperisen [30], about $40 \%$ of the global arable land is acidic and in south and south-east Asia, more than 100 million ha of land is unused due to soil acidity and problems associated it [31]. In India alone, 49 million ha of the 
total land area is affected by soil acidity out of which 24 million ha have $\mathrm{pH}$ below 5.5 [32]. Also, 6\% of total land area and 30\% in irrigated lands is affected by salinity [33]. This leads to massive loss in terms of productivity and arable land, as most of the economically important, particularly horticultural crops are sensitive to soil acidity and salinity. Chilli plants are considered moderately sensitive to salt stress $[34,35]$. However, the high soil salinity leads to poor germination, delays stand establishment, and reduces subsequent growth and yield [36-38]. Yield reduction begins when the electrical conductivity (EC) of saturated soil extraction is greater than $1.5 \mathrm{dS} / \mathrm{m}$ [34]. The chilli plants which were given salt treatment showed drastic reduction in growth parameters, along with reduced chlorophyll content and accumulation of proline [39]. Chillies can grow well under slightly acidic soil conditions. However, very low soil $\mathrm{pH}$ is not suitable for growing most of the crops including chilli. The main problem associated with acidic soil is the immobilization of macro nutrient i.e. phosphorus that rapidly converts into insoluble complexes due to precipitation reaction with $\mathrm{Al}^{3+}$ and $\mathrm{Fe}^{3+}[40,41]$.

\section{Mitigation and Adaptation Strategies}

There are several technologies which are available such as breeding for developing tolerant varieties that can be useful for reducing the impact of climate change. Application of genetic engineering and advanced breeding techniques for developing plants resistant to environmental stress, especially drought is well reviewed by $\mathrm{Hu}$ and Xiong [42]. The extent of information that breeders have now offers them advanced tools for breeding, such as markers for QTLs and single genes for genetic transformation techniques [43]. Use of drip irrigation technology can help in proper utilization of the water from a limited source during critical growth period of chilli and other crops as well. In areas where water scarcity is the main problem, the soil moisture can be preserved by following the practice of mulching, which not only helps in reducing evaporation loss of soil water, but also helps in maintaining soil temperature and reduces weeds from the chilli growing field [44]. The loss of yield by insect pests (such as thrips) and diseases (like leaf spot, leaf curl) can be prevented by developing hybrid varieties or by screening for a genotype which can tolerate insect pest and disease infestation [45]. Through genetic engineering approaches, various biochemical pathways of the plants can be manipulated in order to make the crop plants tolerant to abiotic stresses caused by climate change, for example, the over expression of heat shock protein, proline and abscisic acid as it helps in adaptation of crop plants to withstand drought and salt stress [46]. The genes that are responsible for encoding proteins that are related to calmodulin, calmodulin-binding, zincfinger, putative cyclases, stress related and novel proteins are found to be playing a role in providing tolerance against salt stress [47]. Therefore, these genes can be utilized in developing chilli plants that can grow well under salt stress conditions. Another way of improving the crop yield under drought stress is to develop varieties which have high EUW (Effective use of water) ability, which implies maximal soil moisture capture for transpiration, reduced non stomatal transpiration and minimal water loss by soil evaporation [48]. Osmolyte accumulation $(\mathrm{OA})$ is frequently cited as a key mechanism for increasing productivity of the crops that are under drought conditions. The role of osmolyte accumulation in drought resistance has been reviewed elaborately by Serraj and Sinclair [49]. Several studies have been conducted on tissue culture of chilli and suitable regeneration media for different genotypes of chilli have been standardized [50]. Tissue culture/micropropagation techniques can be utilized to produce a large number of seedlings from a limited initial material as this will help in overcoming the problem of germination in chilli. Also the plant tissue culture may generate genetic variability (somaclonal variation) that may produce variants with desirable characters such as resistance to biotic and abiotic stresses [51]. Plant growth promoting rhizobacteria (PGPR) have strong potential to be successful biofertilizers and bioenhacers. Therefore, they can be used in areas where soil fertility is a major problem [52]. Some other simple but effective adaptation strategies include growing chilli crop in a raised bed to avoid damage from excess water during heavy land preparation of proper drainage system will reduce the adversity of heavy rain and floods on growing crop. Change in the sowing date may help in escaping insect pest and diseases, use of soil and moisture conservations measures will help in judicious utilization of water during drought season and liming on the acidic soil helps in reducing the concentration of toxic elements such as $\mathrm{AL}^{3+}$ and $\mathrm{Fe}^{3+}$ which decreases the immobilization of available phosphorus in the soil [53]. Fertilizers management through fertigation, adjustment in cropping pattern, developing suitable agronomic adaptation measures for reducing the adverse climate related production losses, developing crop simulation models for crops for enabling regional impact adaptation and vulnerability analysis, identification and refinement of indigenous technological knowledge to meet the challenges of weather related damages and developing storage systems for pre and post-harvest produce can reduce the risk of damage caused by climate change.

\section{References}

1. Kothari SL, Joshi A, Kachhawaha S, Ochoa-Alejo N (2010) Chilli Pepper-a review on tissue culture and transgenics. Biotechnol Adv 28: 35-48.

2. Channappagoudar SB (2007) Studies on in vitro regeneration and genetic transformation in chilli (Capsicum annuum L). University of Agriculture Science.

3. Indiastat.com (2015)

4. Chilli Outlook (2018).

5. Indiaspices.com (2017).

6. IPCC (2007) Summary for policymakers. In: Solomon S, Qin D, Manning M Marquis M, Averyt $\mathrm{K}$ et al. (ed) The physical science basis Contribution of working group I to the fourth assessment report of the Intergovernmental Panel on Climate Change Cambridge University Press, United Kingdom Pp 2-22.

7. Sarada C, Ratnam M, Naidu LN, Ramana CV, Rajani A, et al. (2015) Chilli production and productivity in relation to seasonal weather conditions in Guntur district of Andhra Pradesh. Int J Pure App Biosci 3: 207-213.

8. Cabral NSS, Medeiros AM, Neves LG, Sudre CP, Pimenta S, et al. (2017) Genotype $x$ environment interaction on experimental hybrids of chili pepper. Genet Mol Res 20: 16

9. Data Portal India (2013) Annual and seasonal mean temperature of India National informatics centre of govt of India.

10. Yanez-Lopez R, Torres-Pacheco I, Guevara-Gonzalez RG, Hernandez-Zu MI, Quijano-Carranza JA, et al. (2012) The effect of climate change on plant diseases. African Journal of Biotechnology 11: 2417-2428.

11. Erickson AN, Markhart AH (2001) Flower production, fruit set, and physiology of bell pepper during elevated temperature and vapor pressure deficit. J Amer Soc Hort Sci 126: 697-702.

12. Garruna-Hernandez R, Orellana R, Larque-Saavedra A, Canto A (2014) Understanding the physiological responses of a tropical crop (Capsicum chinense Jacq) at high temperature. Plos one 3: 9

13. Aloni B, Pressman E, Karni L (1999) The effect of fruit load, defoliation and night temperature on the morphology of pepper flowers and on fruit shape. Ann Bot 83: 529-534.

14. Rylski I (1972) Effect of the early environment on flowering in pepper (Capsicum annuum L). J Amer Soc Hort Sci 97: 648-651.

15. Si Y, Heins RD (1996) Influence of day and night temperatures on sweet pepper seedling development. J Amer Soc Hort Sci 121: 699-704.

16. Shin JW, Yun SC (2010) Elevated $\mathrm{CO}_{2}$ and temperature effects on the incidence of four major chili pepper diseases. Plant Pathol J 26: 180-184. 
Citation: Bhutia KL, Khanna VK, Meetei TNG, Bhutia ND (2018) Effects of Climate Change on Growth and Development of Chilli. Agrotechnology 7: 180. doi: $10.4172 / 2168-9881.1000180$

Page 4 of 4

17. Roggero P, Dellavalle G, Ciuffo M, Pennazio S (1999) Effects of temperature on infection in Capsicum sp and Nicotiana benthamiana by impatiens necrotic spot tospovirus. Eur J Plant Pathol 105: 509-512.

18. Dodd IC, He J, Turnbull CG, Lee SK, Critchley C (2000) The influence of supra-optimal root-zone temperatures on growth and stomatal conductance in Capsicum annuum L. J Exp Bot 51: 239-48.

19. Aloni B, Peet M, Pharr M, Karni L (2001)The effect of high temperature and high atmospheric $\mathrm{CO}_{2}$ on carbohydrate changes in bell pepper (Capsicum annuum) pollen in relation to its germination. Physiol Plant 112: 505-512.

20. Rahman MJ, Inden H, Hossain MM (2012) Capsaicin content in sweet pepper (Capsicum annuum L) under temperature stress. Acta Hort 396: 195-202.

21. Gunawardena MDM, De Silva CS (2014) Identifying the impact of temperature and water stress on growth and yield parameters of chilli (Capsicum annuum L). OUSL Journal 7: 25-42.

22. Ayyogari K, Sidhya P, Pandit MK (2014) Impact of Climate Change on Vegetable Cultivation - A Review. IJAEB 7: 145-155.

23. Kumar V, Jain SK, Singh Y (2010) Analysis of long-term rainfall trends in India. Hydrolog Sci J 55: 484-496.

24. Alexandratos N, Bruinsma J (2012) World agriculture towards 2030/2050: the 2012 revision. Food and Agriculture Organization of the United Nations, ESA Working Paper No. 12-03.

25. Pena R, Hughes J (2007) Improving vegetable productivity in a variable and changing climate. SAT e journal 4: 1-22.

26. Phimchan P, Techawongstien S (2012) Impact of drought stress on the accumulation of capsaicinoids in Capsicum cultivars with different initial capsaicinoid levels. Hort Science 47: 1204-1209.

27. Khan MAI, Hoque MA, Farooque AM, Habiba U, Rahim MA (2012) Physiomorphological features of chilli accessions under moisture stress conditions. Bangladesh J Agril Res 37: 263-269.

28. Waiganjo MM, Gitonga LM, Mueke JM (2008) Effects of weather on thrips population dynamics and its implications on the thrips pest management. Afr J Hort Sci 1: 82-90.

29. Ram S, Patnaik NC, Mohapatra AKB, Sahoo S, Samal KC (1996) Effects of fertility levels and chilli varieties on the yield of green chillies and incidence of chilli thrips Scirtothrips dorsalis Hood in Eastern Ghat highland zone of Orissa. Environment and Ecology 14: 642-645.

30. Brunner I, Sperisen C (2013) Aluminium exclusion and aluminium tolerance in woody plants. Front Plant Sci 4: 1-12

31. Ismail AM, Heuer S, Thomson MJ, Wissuwa M (2007) Genetic and genomic approaches to develop rice germplasm for problem soils. Plant Mol Biol 65: 547-570.

32. Kumar M, Khan MH, Singh P, Ngachan SV, Rajkhowa DJ, et al. (2012) Variable lime requirement based on differences in organic matter content of iso-acidic soils. Indian J Hill Farming 25: 26-30.

33. Fahad S, Hussain S, Matloob A, Khan FA, Khaliq A, et al. (2014) Phytohormones and plant responses to salinity stress: a review. Plant Growth Reg 75: 391-404.

34. Maas EV, Hoffman GJ (1977) Crop salt tolerance-current assessment. J Irrig Drain 103: 115-134.

35. Pasternak D, Malach YD (1994) Crop irrigation with saline water, In: Pessarakli M (ed) Handbook of plant and crop stress Pp 599-622.
36. Niu G, Rodriguez DS (2010) Salinity and soil type effects on emergence and growth of pepper seedlings. Hort Science 45: 1265-1269.

37. Azuma R, Ito N, Nakayama N, Suwa R, Nguyen NT (2010) Fruits are more sensitive to salinity than leaves and stems in pepper plants (Capsicum annuum L). Sci Hortic 125: 171-180.

38. Butt M, Ayyub CM, Amjad M, Ahmad R (2016) Proline application enhances growth of chilli by improving physiological and biochemical attributes under salt stress. Pak J Agri Sci 53: 43-49.

39. Sharma C, Singh N, Pal K (2012) The effect of salt stress on biochemicals of chilli at seedling level. IJPPR 3: 572-577.

40. Mehta P, Walia A, Kulshrestha S, Chauhan A, Shirkot CK (2014) Efficiency of plant growth-promoting P-solubilizing Bacillus circulans CB7 for enhancement of tomato growth under net house conditions. J Basic Microb 53: 1-12.

41. Das S, Tyagi W, Rai M, Yumnam JS (2017) Understanding Fe2+ toxicity and $P$ deficiency tolerance in rice for enhancing productivity under acidic soils. Biotechnol Genet Eng Rev 33: 97-117.

42. $\mathrm{Hu} \mathrm{H}$, Xiong $\mathrm{L}$ (2014) Genetic engineering and breeding of drought-resistant crops. Annu Rev Plant Biol 65: 715-741.

43. Cattivelli L, Stanca AM (2008) Drought tolerance improvement in crop plants: An integrated view from breeding to genomics. Field Crop Res 105: 1-14.

44. Ashrafuzzaman M, Halim MA, Ismail MR, Shahidullah SM, Hossain MA (2011) Effect of plastic mulch on growth and yield of chilli (Capsicum annuum $\mathrm{L}$ ). Braz Arch Biol Technol 54: 321-330.

45. Bhutia ND, Seth T, Shende VD, Dutta S, Chattopadhyay A (2015) Estimation of heterosis, dominance effect and genetic control of freshfruit yield, quality and leaf curl disease severity traits of chilli pepper (Capsicum annuum L). Sci Hortic 182: 47-55.

46. Xiong $L$ (2007) Abscisic acid in plant response and adaptation to drought and salt stress. In: Jenks MA, Hasegawa PM, Jain SM (ed) Advances in molecular breeding toward drought and salt tolerant crops. Springer pp 193-221.

47. Jhou F, Sosa J, Feldmann KA (2007) High throughput approaches for the identification of salt tolerance genes in plants. In: Jenks MA, Hasegawa PM Jain SM (ed) Advances in molecular breeding toward drought and salt tolerant crops. Springer pp 359-379.

48. Blum A (2009) Effective use of water (EUW) and not water-use-efficiency (WUE) is the target of crop yield improvement under drought stress. Field Crop Res 112: 119-123.

49. Serraj R, Sinclair TR (2002) Osmolyte accumulation: Can it really help increase crop yield under drought conditions? Plant Cell Environ 25: 333-341.

50. Bhutia KL, Meetei NgT, Khanna VK (2016) In vitro regeneration of Dalle Khursani, an important chilli cultivar of Sikkim, using various explants. Agrotechnol 5:142

51. Krishna H, Alizadeh M, Singh D, Sing U, Chauhan N, et al. (2016) Somaclonal variations and their applications in horticultural crops improvement. 3 Biotech 6: 54 .

52. Datta M, Palit R, Sengupta C, Pandit MK, Banerjee S (2011) Plant growth promoting rhizobacteria enhance growth and yield of chilli (Capsicum annuum L) under field conditions. AUST J Crop Sci 5: 531-536.

53. Nongkran M, Rosamalin NR, Bunjerdluk J, Jumpol Y, Charoen C (2002) Application of lime and N-P-K fertilizer for chilli on Rongsit soil series-very acid phase. WCSS 2205: 1-6 